\title{
"Virtual-real vessel" as an informational pedagogical infrastructure of the Kherson State Maritime Academy
}

Popova G.*

\author{
Kherson State Maritime Academy, Kherson, Ukraine
}

Received: 02.01.2019 Accepted: 01.03.2019

\begin{abstract}
Nowadays increasing the efficiency of using modern technologies is one of the main priorities of the development of higher professional education. The development of technologies, informatization of society requires changes in the professional training of future marine specialists in the formation of their professional competencies. The strategic goal of the development of higher education institutions is the continuous improvement of the information infrastructure, resulting in the development of a higher educational institution. The article is devoted to the questions of pedagogical information infrastructure formation in the higher marine educational institution. The approaches to the definition of "information infrastructure" of the higher educational institution, components, features of the formation and functioning of the structure are analyzed. The purpose of the creation of information pedagogical infrastructure-the availability to information resources and services through the improvement of the quality of educational information is identified. In the context of the identified problems in the article the processes of creating a pedagogical information infrastructure in the system of higher maritime education are disclosed. The experience of using pedagogical information infrastructure in the Kherson State Maritime Academy on the example of "Virtual-Real Ship" is presented. The article describes the tasks, the main components of the pedagogical information infrastructure. An example of the use of the electronic environment, LMS Moodle, shows the possibility of developing, creating and implementing a unified system that combines electronic courses and simulators, contains a mechanism for obtaining knowledge and its evaluation. It is shown that the creation of a pedagogical information infrastructure in order to form the professional competencies of future marine specialists is a powerful and promising mechanism in higher marine education. The article concludes that the problem of creating the informational pedagogical infrastructure of a higher maritime educational institution is very relevant and requires an integrated approach and a priority solution to the development of society's digitization.
\end{abstract}

Key words: information infrastructure of higher educational institution, marine specialists, simulation technologies.

\section{«Віртуально-реальне судно» як інформаційна педагогічна інфраструктура Херсонської державної морської академії}

Попова Г. В.

Херсонська державна морська академія, Херсон, Україна

\begin{abstract}
Анотація. В сучасних умовах підвищення ефективності використання інформаційних технологій є одним із найголовніших пріоритетів розвитку вищої професійної освіти. Розвиток технологій, інсформатизація суспільства потребує змін в професійній підготовці майбутніх морських спеціалістів при формуванні їх профресійних компетентностей. Стратегічною задачею розвитку закладів вищої освіти $€$ постійне удосконалення інформаційної інфраструктури, наслідком чого є розвиток вищого навчального закладу. Стаття присвячена питанням формування педагогічної інформаційної інфрраструктури вищого морського навчального закладу. Проаналізовані підходи до визначення «інформаційної інфрраструктури» вищого навчального закладу, компоненти та складові, особливості формування та функціонування структури. Визначена мета створення інфрормаційної педагогічної інфрраструктури- доступність до інформаційних ресурсів та сервісів через підвищення якості навчальної інфоомації. В контексті визначеної проблематики у статті розкрито процеси створення педагогічної інформаційної інфраструктури у системі вищої морської освіти. Представлений досвід використання педагогічної інформаційної інфрраструктури в Херсонській державній морській академії на прикладі «Віртуально-реального судна». В статті описані завдання, основні компоненти педагогічної інфформаційної інфрраструктури. На прикладі застосування електронного середовища LMS Moodle
\end{abstract}

Corresponding Author: Popova Galina Viktorivna. Tel. +38(066) 33-30-560. E-mail: spagalina@gmail.com Kherson State Maritime Academy, pr. Tekstilnikiv, 14a., kv.17, Kherson, Ukraine, 73028.

Відповідальний автор: Попова Галина Вікторівна. Tel. +38(066) 33-30-560. E-mail: spagalina@gmail.com Херсонська державна морська академія, пр. Текстильників, 14а, кв.17, Херсон, Україна, 73028. 
показана можливість розробки, створення та запровадження єдиної системи, яка поєднує електронні курси і тренажери, містить механізм отримання знань і оцінку. Показано, що створення педагогічної інформаційної інфраструктури з метою формування професійних компетентностей майбутніх морських фрахівців $є$ потужним та перспективним механізмом у вищій морській освіті. В статі робиться висновок, що проблема створення інформаційної педагогічної інфраструктури вищого морського навчального закладу є досить актуальною, і потребує комплексного підходу та першочергового вирішення на шляху розвитку цифровізації суспільства. Ключові слова: інформаційна інфраструктура вищого навчального закладу, морські спеціалісти, симуляційні технології.

\title{
«Виртуально-реальное судно» как информационная педагогическая инфраструктура Херсонской государственной морской академии
}

\author{
Попова Г. В.
}

\author{
Херсонская государственная морская академия, Херсон, Украина
}

\begin{abstract}
Аннотация. В современных условиях повышение эффективности использования информационных технологий есть одним из главных приоритетов развития высшего профессионального образования. Развитие технологий, информатизация общества требует изменений в профессиональной подготовке будущих морских специалистов при фрормировании их профессиональных компетентностей. Стратегической задачей развития высших учебных заведений является постоянное совершенствование информационной инфраструктуры, следствием чего является развитие высшего учебного заведения. Статья посвящена вопросам формированию педагогической информационной инфраструктуры высшего морского учебного заведения. Проанализированы подходы к определению «информационной инфраструктуры» высшего учебного заведения, компоненты и составляющие, особенности формирования и функционирования структуры. Определена цель создания информационной педагогической инфраструктуры - доступность к информационным ресурсам и сервисам через повышение качества учебной информации. В контексте определенной проблематики в статье раскрыты процессы создания педагогической информационной инфраструктуры в системе высшего морского образования. Представлен опыт использования педагогической информационной инфраструктуры В Херсонской государственной морской академии на примере «Виртуально-реального судна». В статье описаны задачи, основные компоненты педагогической информационной инфраструктуры. На примере использования электронной среды LMS Moodle показана возможность разработки, создания и внедрения единой системы, которая соединяет электронные курсы и тренажеры, содержит механизм получения знаний и оценку. Показано, что создание педагогической информационной инфраструктуры с целью формирования профессиональных компетентностей будущих морских специалистов является мощным и перспективным механизмом в высшем морском образовании. В статье делается вывод, что проблема создания информационной педагогической инфраструктуры высшего морского учебного заведения является весьма актуальной, и требует комплексного подхода и первоочередного решения на пути развития цифровизации общества.

Ключевые слова: информационная инфраструктура высшего учебного заведения, морские специалисты, симуляционные технологии.
\end{abstract}

\section{Bcmyn}

На сучасному етапі роль інформаційного забезпечення освітнього процесу вищого навчального закладу стає все більш вагомою та домінуючою тенденцією. Стратегічною задачею розвитку 3 ВО $є$ постійне удосконалення інформаційної інфрраструктури, наслідком чого є розвиток вищого навчального закладу. Нові умови функціонування освітніх закладів вимагають змін підходів до управління та організації функціонування педагогічного середовища.

Як зазначають дослідники Крюков В.В., Шахгельдян К.І. [1]., на сучасному етапі інформаційне середовище із засобів надання доступу до необхідної інформації перетворюється в обов'язковий компонент інфраструктури управління та сукупність інтелектуальних сервісів, без яких неможливо забезпечити управління та якісне навчання у вищому навчальному закладі.

Питаннями навчальних середовищ в освітніх закладах займалися такі науковці: Крюков В.В., Мамикова Ж.Д., Алісултанова Е.Д.,, Соколова О.І. , Кухаренко В.В. та ін.

Серед напрямків розвитку інфраструктури ЗВО окремо виділяють інфрормаційні ресурси та сервіси освітнього середовища вузу, які використовуються при організації освітнього процесу студентів [2].

Так, R.Кау [3] вважає що при побудові віртуального інформаційного середовища необхідно не тільки враховувати технічні компоненти, а й обов'язково надавати студентам максимально більшу 
кількість підказок, посилань, орієнтувань в віртуальному середовищі, що надасть змогу створити єдиний простір навчання.

D.Otto [4], досліджуючи віртуальну мобільність, стверджує про можливість інформаційного обміну між інформаційними середовищами освітніх закладів для накопичення міжнародного досвіду.

Проаналізувавши дані досліджень щодо визначення інформаційної інфраструктури в 3ВО (табл.1), можна стверджувати, що більшість науковців вважають інформаційну інфраструктуру інформаційним середовищем, де здійснюється інтеграція всіх ресурсів, обробка інформації та надання інформаційних послуг.

Табл. 1. Дані з інфрормаційної інфрраструктури в 3ВО

\begin{tabular}{|c|c|c|c|}
\hline 1 & 2 & 3 & 4 \\
\hline 1 & $\begin{array}{l}\text { Мамыкова Ж.Д., } \\
\text { Мутанов Г.М. [5] }\end{array}$ & $\begin{array}{l}\text { IT- } \\
\text { інфрраструктура }\end{array}$ & $\begin{array}{l}\text { IT-інфраструктура - комплекс апаратних, програмних і } \\
\text { телекомунікаційних засобів, що забезпечують реалізацію } \\
\text { процесів обробки ІТ-ресурсів з метою надання } \\
\text { інфрормаційних послуг, необхідних для здійснення } \\
\text { професійної діяльности і вирішення поточних завдань, що } \\
\text { стоять перед студентами, викладачами,науковцями та } \\
\text { співробітниками, а також перед відповідними підрозділами } \\
\text { зВО. }\end{array}$ \\
\hline 2 & $\begin{array}{l}\text { Крюков В. В, } \\
\text { Шахгельдян К.И. } \\
\text { [1] }\end{array}$ & $\begin{array}{l}\text { Корпоративне } \\
\text { інфформаційне } \\
\text { середовище }\end{array}$ & $\begin{array}{l}\text { Корпоративне інформаційне середовище забезпечує } \\
\text { інтеграцію інфрормаційних ресурсів і дозволяє } \\
\text { автоматизувати бізнес-процеси у відповідності до діючої } \\
\text { організаційної структури та визначеними в ЗВО бізнес- } \\
\text { правилами; із засоба надання доступу до необхідної } \\
\text { інфрормації перетворилася в обов'язковий компонент } \\
\text { інфрраструктури управління та сукупністі інтелектуальних } \\
\text { сервісів, без яких неможливо забезпечити ефективне } \\
\text { управління і якісне навчання в 3ВО. }\end{array}$ \\
\hline 3 & $\begin{array}{l}\text { Алисултанова } \\
\text { Э.Д., } \\
\text { Моисеенко Н.А., } \\
\text { Бисултанова } \\
\text { А.А., } \\
\text { Дадашова А.С. } \\
\text { [6] }\end{array}$ & $\begin{array}{l}\text { Мережева } \\
\text { інсрраструктура }\end{array}$ & $\begin{array}{l}\text { Мережева інфрраструктура ЗВО - це середовище } \\
\text { інформаційної взаємодії, що дає можливість реалізувати } \\
\text { освітні потреби; забезпечується спеціальними апаратними } \\
\text { та програмними засобами; комплекс мережевої взаємодії } \\
\text { включає в себе засоби комунікацій між людьми (електронна } \\
\text { пошта, чати, форуми, відеоконференції і т.п.), засоби } \\
\text { доступу до інфформаційних навчальних ресурсів: зовнішні та } \\
\text { внутрішні. }\end{array}$ \\
\hline 4 & Соколова О.И. [7] & $\begin{array}{l}\text { Інформаційна } \\
\text { інфрраструктура }\end{array}$ & $\begin{array}{l}\text { Інформаційна інфраструктурає організаційно- } \\
\text { інфрормаційною базою освітніх установ; це відкрита } \\
\text { інформаційна система, що включає сукупність } \\
\text { інфрормаційнихцентрів, банків даних і знань, систем зв'язку, } \\
\text { взаємопов'язаних обслуговуючих структур, що складають } \\
\text { основу для вирішення поставленої проблеми (завдання); } \\
\text { забезпечує доступ споживачів до інформаційних ресурсів і } \\
\text { здійснює освітні наукові комунікації, актуальні для } \\
\text { реалізації цілей і завдань освіти і розвитку педагогічної } \\
\text { науки в сучасних умовах. }\end{array}$ \\
\hline 5 & $\begin{array}{l}\text { Каракозов С.Д. } \\
\text { [8] }\end{array}$ & $\begin{array}{l}\text { Інформаційна } \\
\text { інфрраструктура }\end{array}$ & $\begin{array}{l}\text { Організаційні структури і середовище інформаційної } \\
\text { взаємодії утворюють інформаційну інфраструктуру; має } \\
\text { на меті об'єднатиінфрормаційно-телекомунікаційні системи } \\
\text { підрозділів; з метою подолана роз'єднаності джерелів } \\
\text { інфрормації, покращення обміну інформацією та доступу до } \\
\text { неї. }\end{array}$ \\
\hline
\end{tabular}




\begin{tabular}{|c|c|c|c|}
\hline 1 & 2 & 3 & 4 \\
\hline \multirow[t]{3}{*}{6} & $\begin{array}{l}\text { Волкова В.Н., } \\
\text { Голуб Ю.А. [9] }\end{array}$ & $\begin{array}{l}\text { Інформаційна } \\
\text { інфраструктура }\end{array}$ & $\begin{array}{l}\text { Інформаційна інфраструктура ЗВО - сукупність цілей } \\
\text { (потреб), структур, технологій, умов існування системи, } \\
\text { користувачів, для яких вона створюється і часу існування } \\
\text { системи:, де Z - цілі (потреби); STR - структури; ТECH - } \\
\text { технології, включаючи методи, засоби, алгоритми, } \\
\text { програми; COND - умови (фрактори, що впливають на } \\
\text { створення та функціонування системи; Ne користувачі, } \\
\text { розробники; Т - час існування системи }\end{array}$ \\
\hline & $\begin{array}{l}\text { Д.3. Смагулов, } \\
\text { Д.Б. Алибиев } \\
\text { [10] }\end{array}$ & $\begin{array}{l}\text { Інформаційна } \\
\text { інфраструктура }\end{array}$ & $\begin{array}{l}\text { Ефективне функціонування і управління закладом вищої } \\
\text { освіти передбачає наявність розвиненої інформаційної } \\
\text { інфрраструктури на основі нових інформаційних технологій; } \\
\text { для фрормування баз даних інфрормаційних освітніх ресурсів, } \\
\text { що містять структуровану нормативну, навчальну, наукову, } \\
\text { довідкову, фактограффічну та іншу інфформацію; включає } \\
\text { ефективні засоби аналізу ділової та іншої інформації. }\end{array}$ \\
\hline & Іванов О.В. [11] & $\begin{array}{l}\text { Інформаційна } \\
\text { інфрраструктура }\end{array}$ & $\begin{array}{l}\text { Інформаційна інфрраструктура - критерій ефрективності } \\
\text { інфрорматизації в освітньому закладі вищої освіти. }\end{array}$ \\
\hline 7 & Tiiu Tenno [11] & $\begin{array}{l}\text { Педагогічна } \\
\text { інффраструктура }\end{array}$ & $\begin{array}{l}\text { Практика навчання, а також середовище веб-навчання та } \\
\text { його змістові елементи. }\end{array}$ \\
\hline 8 & Lakkala et al [11] & $\begin{array}{l}\text { Педагогічна } \\
\text { інфрраструктура }\end{array}$ & $\begin{array}{l}\text { Пропонує до педагогічної інфраструктури включати технічні, } \\
\text { соціальні, гносеологічні та когнітивні компоненти. }\end{array}$ \\
\hline
\end{tabular}

Існують відмінності у визначеннях, так зустрічаються терміни «корпоративне інформаційне середовище», «мережева інфраструктура», але більшість науковців дають визначення «інформаційна інфрраструктура». Заслуговує на увагу дослідження Carol A. Twigg [12] про необхідність створення національної інфраструктури навчання, тому що педагогічна модель, що використовується в сучасній педагогічній інфраструктурі базується на концепції індустріальної епохи і не може запропонувати високоякісний досвід навчання.

W. Lewis Johnson [13] та Jamshid Beheshti [14] пропонують створення та використання інформаційного середовища на основі конструктивістського підходу, що є ефективними для розробки ресурсів для вирішення проблеми сучасній молоді, що звикли до віртуальних середовищ в ігровій діяльності.

Під інфрормаційною педагогічною інфраструктурою ЗВО ми будемо розуміти комплекс матеріально-технічних, програмових, телекомунікаційних засобів, інформаційних ресурсів та сервісів, педагогічних технологій та методик, що забезпечують здійснення педагогічної діяльності з метою формування професійних компетентностей студентів.

Аналіз стану інформатизації в ЗВО свідчить, що на даний момент існують певні труднощі в організації інформаційного середовища. Так, дуже часто всі компоненти системи існують окремо, не мають зв'язку і використовуються за репродуктивною моделлю, де викладач залишається в центрі як єдине джерело знань та екзаменатор. Інформація залишається ізольованою, на пошуки якої уходить великий ресурс часу. Так, наприклад, знайти відповідального на кафедрі, хто має доступ до інформації та переписати у нього на фрлешку завдання та вимоги до виконання практичних робіт займає велику кількість часу в порівнянні з інформацією он-лайн, доступ до якої відкритий цілодобово. Прикладом неефективного використання інформаційних потоків $є$ відсутність єдиної точки входу до інформації, що стосується освітнього процесу - велика кількість сайтів кафедр, груп Viber та Telegram, електронних адрес викладачів, лаборантів - все це перетворює на хаос інформаційні потоки вищого навчального закладу і знижує ефективність навчання. Обробка інформації, аналітичні та статистичні звіти часто перетворюються на суцільний жах для відповідальних, тому що інформацію потрібно збирати, пошуки займають великі часові та психоемоційні ресурси, а об'єм роботи зростає із збільшенням інформації.

Побудова інформаційної педагогічною інфраструктури вищого навчального закладу дозволяє покращити управління даними, знаннями, інноваційними процесами, підвищує компетентність всіх 
учасників освітнього процесу і надає можливість уникнути психоемоційної напруги в соціальному середовищі.

Метою створення такої інфраструктури повинно стати:

- підвищення якості надання освітніх послуг шляхом пошуку нових форм взаємодії в цифровому середовищі;

- оптимізація використання інформаційної техніки шляхом більш досконалого та ефективного її використання;

- доступність до інфрормаційних ресурсів та сервісів через підвищення якості навчальної інформації, регламентованого доступу до ресурсів закладу.

- впровадження новітніх технологій в освітній процес шляхом керування контентом та використанням інноваційних технологій;

- зниження рівня суб'єктивності оцінювання викладачем, уникнення корупційної складової через запровадження системи комп'ютерного тестування.

Як свідчить практика, вирішення проблем інформатизації дозволяє вийти на новий рівень функціонування освітнього закладу, де взаємна узгодженість всіх підсистем значно підвищує ефективність діяльності в цілому та забезпечує високу конкурентоспроможність 3ВО.

Тому проблема створення інформаційної педагогічної інфраструктури вищого навчального закладу є досить актуальною, і потребує комплексного підходу та першочергового вирішення на шляху розвитку цифровізації суспільства.

\section{II Матеріал і методи дослідження}

Найбільш повно окреслені вимоги можуть бути реалізовані шляхом створення єдиної педагогічної інфрраструктури на прикладі Херсонської державної морської академії.

Одним із стратегічних завдань розвитку ХДМА $€$ розвиток освітньої, наукової та інноваційної інфраструктури, що забезпечує необхідні умови для максимально ефективного формування професійних компетентностей майбутніх морських спеціалістів, максимальної реалізації професійного та особистісного потенціалу кожного студента і співробітника. При цьому важливу роль відіграє орієнтація на компетентнісний підхід в освітньому процесі, що сприяє підсиленню прикладного, практичного характеру професійної морської освіти.

Підґрунтям створення інформаційної інфрраструктури $€$ матеріально-технічні ресурси. Так, завдяки обладнанню найсучаснішими цифровими засобами навчання з використанням симуляційних технологій: тренажерами віртуальної реальності, моделями-муляжами, манекенами-імітаторами, реальним обладнанням, в ХДМА був створений центр, який отримав назву «Віртуально-реальне судно».

«Віртуально-реальне судно» ХДМА $є$ окремою структурною інноваційною одиницею в системі навчання - повноцінне симуляційне судно - що з'єднує освітню наступність між допрактичним та практичним етапом навчання, і $є$ потужним інструментом по формуванню професійних компетентностей майбутніх морських спеціалістів. Так, в центрі проводиться розробка та запровадження методичного та нормативного забезпечення освітнього процесу, формування індивідуальної освітньої траєкторії, стандартизація критеріїв оцінки знань, вмінь, компетентностей, створюються високотехнологічні стандарти реагування в надзвичайних ситуаціях, що відповідають вимогам Міжнародної конвенції про підготовку та дипломування моряків та несення вахти 78/95 р. з Манільськими поправками 2010 р. (ПДНВ) [15].

\section{III Результати}

Основними задачами центру «Віртуальне реальне судно» визначено наступні:

1) розробка, адаптація та запровадження комплексу організаційно-методичних заходів та сучасних освітніх симуляційних технологій в освітній процес;

2) здійснення освітнього процесу по відпрацюванню та формуванню профресійних компетентностей з використанням сучасних симуляційних технологій; 
3) проведення навчання на муляжах, манекенах, тренажерах віртуальної реальності 3 використанням ситуацій, що моделюються згідно розроблених сценаріїв та програм;

4) інфоормаційне супроводження освітнього процесу в галузі інноваційних технологій, перспективного зарубіжного та вітчизняного досвіду по проблемам морської освіти, організація семінарів, конференцій, майстер-класів;

5) організація науково-дослідної роботи по актуальним проблемам симуляційного навчання.

Використання цифрових технологій в освітньому процесі повинні забезпечувати кваліфіковані викладачі, які здатні працювати в сучасному інформаційно-освітньому середовищі. Для підвищення цифрових компетентностей професорсько-викладацького складу в ХДМА було відкрито лабораторію інноваційних технологій, де проводяться навчання за змішаною технологію на платформі LMS Moodle.

Дослідженням використання платформи LMS Moodle для створення віртуального освітнього середовища займалися такі науковці як Кухаренко В.В.[16],, Корень А.В.[17], Шерман М.І.[18], Волошинов С.А. [18]. Всі дослідження містять результати ефективного застосування віртуального середовища системи LMS Moodle для вищої школи, що має сучасні інноваційні можливості організації електронного навчання та створення єдиної інфрормаційної педагогічної інфрраструктури закладу.

Так, на рис. 1. представлений електронний курс для викладачів ХДМА по формуванню цифрової компетентності викладачів, розроблений в лабораторії інноваційних технологій ХДМА.

\section{Moodle-навчання}

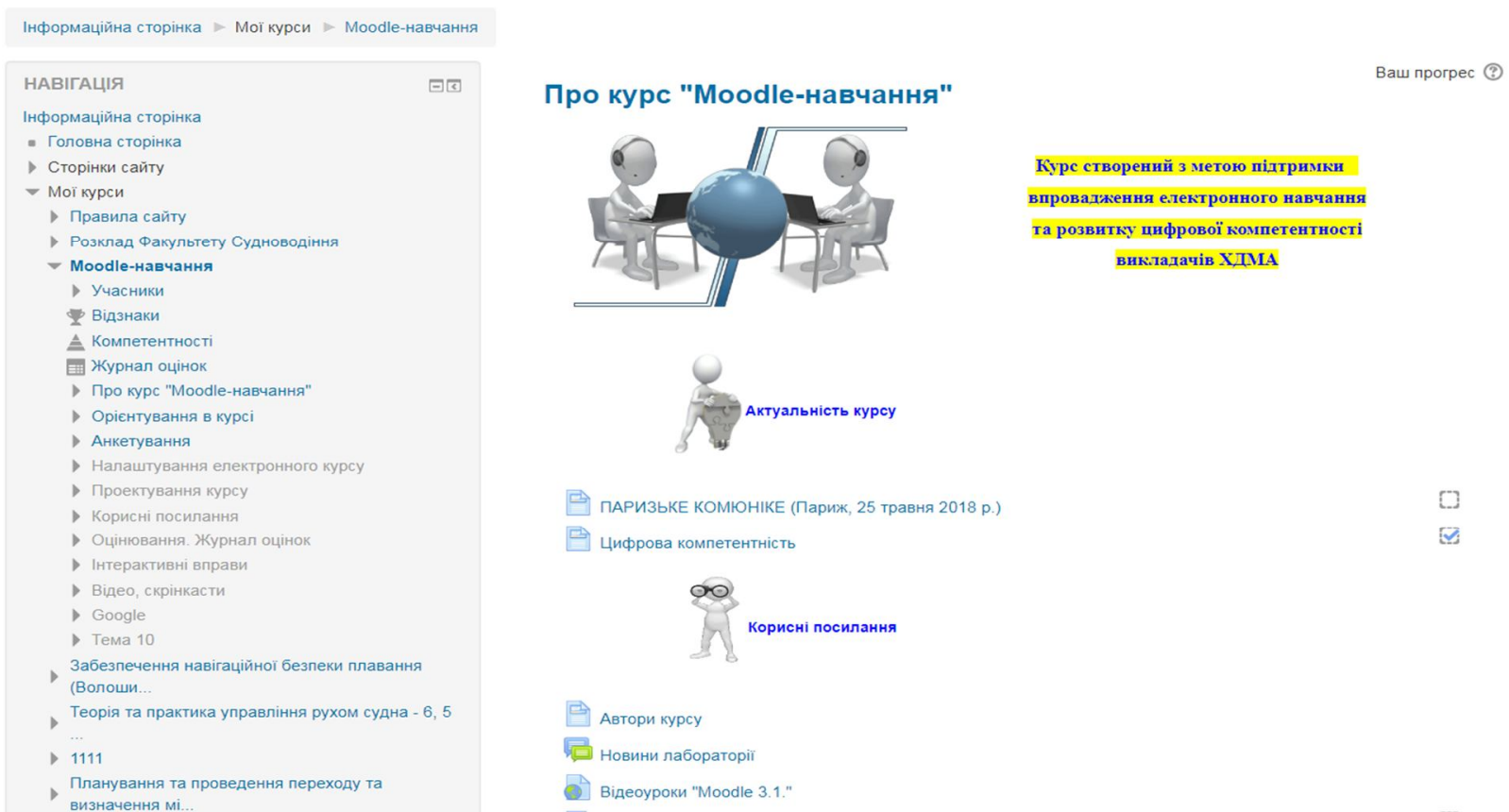

Рис. 1. Електронний курс для викладачів ХДМА «Moodle навчання»

На рис. 2 представлена інформаційна педагогічна інфрраструктура Херсонської державної морської академії. Назва «Віртуально-реальне судно» означає поєднання всіх матеріально-технічних, цифрових та інтелектуальних ресурсів та сервісів в єдину цілісну систему, що має на меті формування профресійних компетентностей майбутніх морських фахівців.

Матеріально-технічне забезпечення представлено парком комп'ютерної та оргтехніки, засобами телекомунікацій і тренажерним центром, який складається із наступних лабораторій:

- Навігаційні інформаційні системи.

- Повнофункціональний навігаційний ходовий місток.

- Повнофункціональний тренажер використання РЛС та ЗАРП при розходженні суден.

- Повнофункціональний тренажер судна з динамічною системою позиціонування.

- Тренажер ГМЗЛБ (Глобального морського зв'язку у разі лиха та для забезпечення безпеки).

- Тренажер з вантажних операцій з великогабаритними вантажами. 
- Боротьба з пожежами.

- Медична допомога на борту судна.

- Охорона судна.

- Повнофункціональний тренажер машинного відділення.

- Повнофункціональний тренажер швартової станції.

- Тренажерний комплекс по кріпленню морських контейнерів.

- Тренажер «Шлюпка вільного падіння».

- Тренажерний комплекс по відпрацюванню навичок безпеки на воді.

- Пожежний полігон.

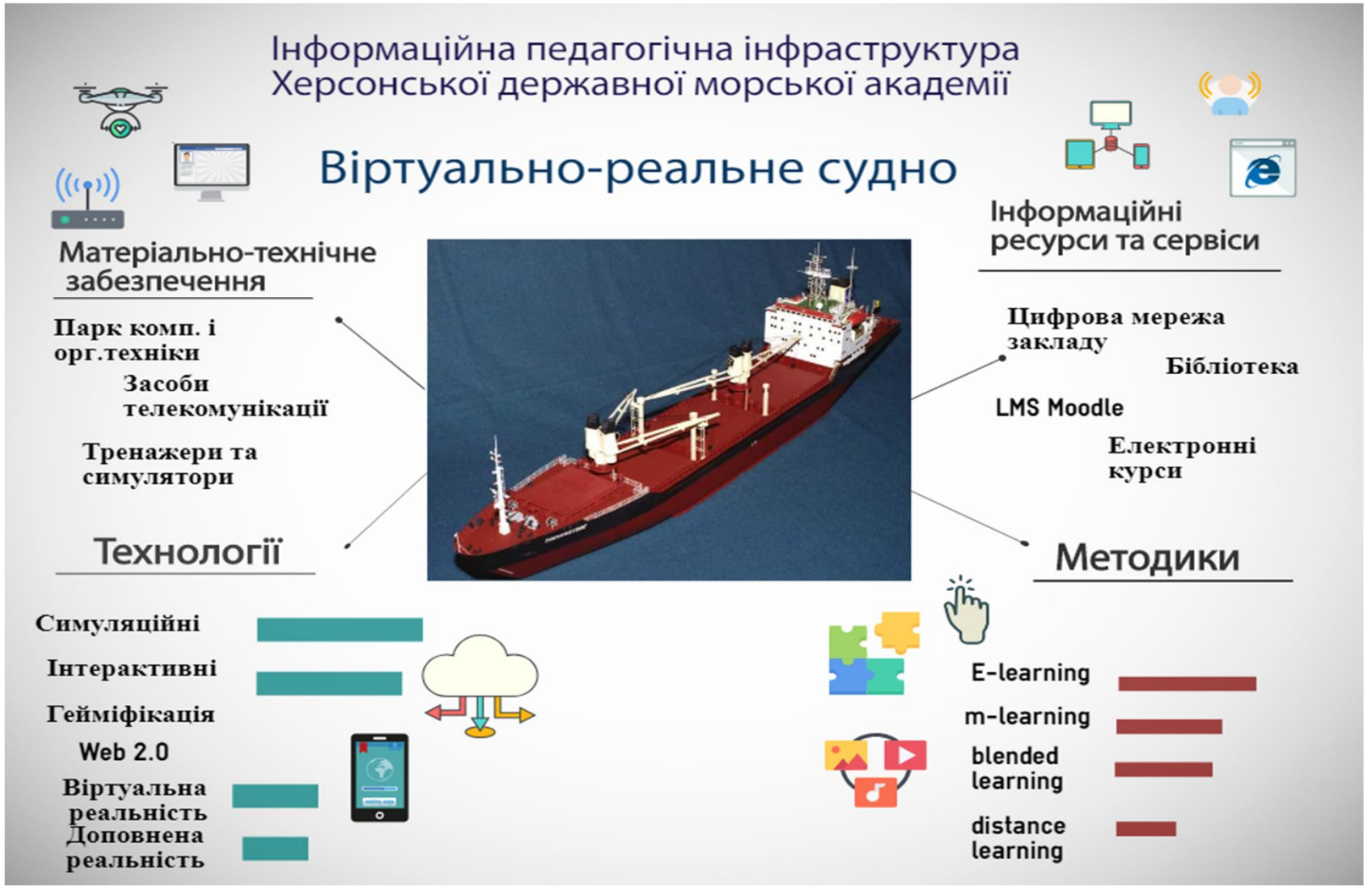

Рис. 2. Інформаційна педагогічна інфрраструктура Херсонської державної морської академії

Електронні тренажери поєднані між собою інформаційними зв'язками і тому можливе використання цієї системи суднових тренажерів як єдиного судна.

Запорука успішного формування професійних компетентностей морських фахівців $€$ наявність глибоких теоретичних знань. 3 цією метою розроблена та впроваджена програма інтегрованого модульного навчання, яка включає два модулі:

1. Електронне навчання на сайті LMS Moodle.

2. Заняття в симуляційному центрі «Віртуально-реальне судно».

У зв'язку з цим виникла необхідність розробки, створення та запровадження єдиної системи, яка б поєднувала і електронний курс і тренажери, що містить механізм отримання знань і оцінку. Розробка такого комплексу була здійснена на платформі LMS Moodle з інтегрованою системою персоналізацією та можливістю авторизованого доступу до свого особистого профрілю, що дозволяє курсанту: систематизувати дані про вже пройдені етапи навчання та обрати подальшу траєкторію розвитку та професійного росту. Викладач має змогу об'єктивно оцінити початковий рівень знань курсанта, формувати індивідуальний підхід навчання та відслідковувати загальну статистику, впливати на динаміку змін ефективності процесу навчання, надавати пропозиції щодо покращення та змін навчальних планів підготовки. 


\section{IV Обговорення}

Наявність таких функціоналів системи LM Moodle як «Шаблон навчальних планів» та «Репозитарій компетентностей» надає можливість відслідковувати набуття професійних компетентностей курсантами, формувати індивідуальні навчальні плани, обирати свій темп навчання, що надає можливість побудови індивідуальних траєкторій навчання [4].

Також до інформаційних ресурсів і сервісів відносяться бібліотека закладу, корпоративна електронна пошта, сайт закладу, де містяться всі інформаційні матеріали.

Одним із завдань, що стоїть перед центром «Віртуально-реальне судно» є розробка, адаптація та запровадження комплексу організаційно-методичних заходів та сучасних освітніх симуляційних технологій в освітній процес. Так, викладачі ХДМА впроваджують в освітній процес змішане, мобільне навчання на платформі LMS Moodle [20], створюють електронні курси, використовуючи сучасні технології Web 2.0, геймісрікацію.

Перевагами користування LMS Moodle для всіх учасників освітнього процесу $є$ доступ до всіх електронних сервісів та ресурсів (Розклади факультетів в режимі он-лайн, розклад викладачів, запис на індивідуальне складання екзаменів тощо); опанування цифровими компетентностями (так, курсанти беруть участь у створенні контенту електронних курсів: ігрові вправи на сервісах Web 2.0., розробка глосаріїв курсу, створення мап, заповнення Google документів тощо); формування інформаційної грамотності (створені курси підтримки орієнтування в цифровому середовищі, опанування навичками розробки контенту).

Таким чином системна концентрація різних технологій в одному циклі формування професійних компетентностей дозволяє курсанту опанувати весь спектр знань та навичок за короткий проміжок часу, що має як економічний ефект так і високу результативність навчання.

\section{V Висновки}

В сучасних умовах запорукою успішного функціонування закладу вищої освіти $є$ наявність необхідної інформаційної педагогічної інфраструктури, що побудована з урахуванням сучасних тенденцій та пріоритетів інформатизації та цифровізації суспільства. Це вимагає реалізації розвитку системи, що буде орієнтована на задоволення потреб всіх учасників освітнього процесу, спрямована на створення високоякісного та високотехнологічного цифрового науково-освітнього середовища. Створення інформаційної педагогічної інфрраструктури - це потужний механізм управління всіма електронними ресурсами та сервісами, що забезпечує відкритість освітнього процесу, здійснення контролю за якістю надання освітніх послуг.

В контексті визначеної проблематики розкрито процеси створення педагогічної інформаційної інфрраструктури у системі вищої морської освіти на прикладі Херсонської державної морської академії. Представлений досвід створення центру «Віртуально-реальне судно», що має на меті формування професійних компетентностей майбутніх морських фахівців, є потужним та перспективним механізмом у

вищій морській освіті. На основі створеної багатофункціональної інформаційної педагогічної інфрраструктури академії здійснюється навчання на симуляторах, електронних тренажерах, проводиться електронне навчання за змішаною моделлю, що значно покращує рівень сфрормованості професійних компетентностей майбутніх морських спеціалістів.

До перспективних напрямків подальших досліджень $€$ встановлення цифрових зв'язків ХДМА з іншими морськими закладами України та світу для обміну цифровими ресурсами, проведення конференцій, вебінарів та обміну досвідом по реалізації змішаного навчання та використання симуляційних технологій.

\section{Бібліографрічні посилання}

[1] Крюков В.В., Шахгельдян К. И. Информационные технологии в университете: стратегии, тенденции, опыт. URL: http://elar.urfu.ru/bitstream/10995/26115/1/unup-2012-04-16.pdf (дата звернення 21.01.2019)

[2] Крюков Д. Н., Васильєва И. Л. Инфрормационная инфраструктура вуза / Высшее образование в России. 2012. Вып. 6. C. $117-120$.

[3] Kay, R. (2018). Exploring best pedagogical practices for virtual classrooms. INTED2018 Proceedings, 5-7 March, 2018, Valencia, Spain, 311-317. doi: https://doi.org/10.21125/inted.2018.0105 
[4] Otto, D. (2018). The challenge of virtual mobility: pedagogical models and good practices. INTED2018 Proceedings, 5-7 March, 2018, Valencia, Spain, 3368-3376. doi: https://doi.org/10.21125/inted.2018.0651

[5] Мамыкова Ж.Д., Мутанов Г.М. ИТ-инфраструктура вуза как платформа для развития информационных технологий./ Вестник НГУЭУ. 2013, №4. С.276-287

[6] Алисултанова Э.Д., Моисеенко Н.А., Бисултанова А.А., Дадашова А.С. К вопросу о формировании инфрраструктуры электронного обучения в техническом вузе. URL: https://www.science-education.ru/ru/article/view?id=26030 (дата звернення 21.01.2019)

[7] Соколова О.И. Особенности управления развитием информационной инфрраструктуры вуза. / Известия вузов. Северо-Кавказский регион. 2006.Спецвыпуск. С.65-67

[8] Каракозов С.Д. Инфформационная инфраструктура Барнаульского государственного педагогического университета: состояние и перспективы развития. URL https://www.altspu.ru/ Resources/Journal/ vestbspu/2001/estestv/ PDF/karakozov.pdf (дата звернення 21.01.2019)

[9] Волкова В.Н., Голуб Ю.А. Оценка компонентов информационной инфрраструктуры вуза. URL http://www.rusnauka.com/9_KPSN_2011/Matemathics/4_84443.doc.htm (дата звернення 21.01.2019)

[10] Смагулов Д.З,Алибиев Д.Б. Роль информатизации учебного процесса в современном вузе/ Вестник КарГУ, 2010. URL https://articlekz.com/article/5662 (дата звернення 21.01.2019)

[11] Иванов О.В. Информационная инфраструктура университета как средство обеспечения нового качества образования. URL https://cyberleninka.ru/article/n/informatsionnaya-infrastruktura-universiteta-kak-sredstvo-obespecheniyanovogo-kachestva-obrazovaniya (дата звернення 21.01.2019)

[12] Tiiu Tenno,Pedagogical infrastuctures in e-learning enviroments as invisible bridges between navigation elements URL https://www.ulapland.filloader.aspx?id=c8c856b7-cef0-4761-9d6e-f50fc0f45379 (дата звернення 21.01.2019)

[13] Carol A. Twigg. The Need For A National Learning Infrastructure. URL https://www.educause.edu/ir/library/html/nlio001.html (дата звернення 21.01.2019)

[14] Johnson, W. L. (2002). Natural Interaction With Pedagogical Agents in Virtual Environments. doi: https://doi.org/10.21236/ ada409186

[15] Jamshid Beheshti Eichenberg, C. (Ed.) (2012). Virtual Reality in Psychological, Medical and Pedagogical Applications. IntechOpen. doi: https://doi.org/10.5772/2607

[16] Міжнародна конвенція про підготовку і дипломування моряків та несення вахти 1978 року (консолідований текст 3 манільськими поправками). К. : Україна, 2012.

[17] Корень А.В. Использование электронной образовательной среды Moodle в создании интерактивных учебных курсов нового поколения / Інтернет-журнал Науковедение.2013.№1. URL https://cyberleninka.ru/article/n/osobennosti-razrabotkiuchebnyh-kursov-s-ispolzovaniem-elektronnoy-obrazovatelnoy-sredy-moodle (дата звернення 21.01.2019)

[18] Шерман M.І., Волошинов С.А., Попова Г.В. Організація змішаного навчання в електронному середовищі LMS Moodle 3 використанням функціоналу управління компетентностями. URL: http://2018.moodlemoot.in.ua/course/view.php?id=39 (дата звернення 10.12.2018)

[19] Кухаренко В. М.,. Березенська С. М, Бугайчук ..Л.Теорія та практика змішаного навчання : монографія / В. М. Кухаренко. - Харків: Міськдрук. 2016. - 284 С.

[20] Yurzhenko A., Sherman M., Popova H. Interactive course «Maritime English» in the professional training of future» in Development trends in pedagogical and psychological sciences: the experience of countries of Eastern Europe and prospects of Ukraine, LV-1058, Riga, Latvia: Baltija Publishing, 2018, pp. 603-620.

\section{References}

[1] Kryukov, V.V., Shahgeldyan, K.I. (2012). Information technology at the university: strategies, trends, experience. URL: http://elar.urfu.ru/bitstream/10995/26115/1/unup-2012-04-16.pdf (accessed 21.01.2019) [in Russian]

[2] Kryukov, D.N., Vasilyva, I.L (2012). Higher education institution's information infrastructure. Vyisshee obrazovanie v Rossii,, 6, 117-120 [in Russian]

[3] Kay, R. (2018). Exploring best pedagogical practices for virtual classrooms. INTED2018 Proceedings, 5-7 March, 2018, Valencia, Spain, 311-317. doi: https://doi.org/10.21125/inted.2018.0105

[4] Otto, D. (2018). The challenge of virtual mobility: pedagogical models and good practices. INTED2018 Proceedings, 5-7 March, 2018, Valencia, Spain, 3368-3376. doi: https://doi.org/10.21125/inted.2018.0651

[5] Mamykova, Zh.D., Mutanov, G.M. (2013). IT infrastructure of the higher education institution as a platform for the development of information technology./ Vestnik NGUEU, 4, 276-287 [in Russian]

[6] Alisultanova, E.D., Moiseenko, N.A., Bisultanova, A.A., Dadashova, A.S. (2016). To the question of the formation of the infrastructure of e-learning in a technical higher education institution. URL: https://www.scienceeducation.ru/ru/article/view?id=26030 (accessed 21.01.2019) [in Russian]

[7] Sokolova, O.I. (2006). Features of higher education institution's management of the information infrastructure development. Izvestiya vuzov: Severo-Kavkazskij region, Specvypusk, pp. 65-67 [in Russian]

[8] Karakozov, S.D. (2001). Information infrastructure of Barnaul State Pedagogical University: the state and prospects of development. URL: https://www.altspu.ru/Resources/Journal/vestbspu/2001/estestv/PDF/karakozov.pdf (accessed 21.01.2019) [in Russian] 
[9] Volkova, V.N., Golub, Yu.A. (2011). Evaluation of the components of higher education institution's information infrastructure.. URL: http://www.rusnauka.com/9_KPSN_2011/Matemathics/4_84443.doc.htm (accessed 21.01.2019) [in Russian]

[10] Smagulov, D.Z, Alibiev, D.B. (2010).The role of informatization of the educational process in the modern high educational establishment. Vestnik KarGU. URL: https://articlekz.com/article/5662 (accessed 21.01.2019) [in Russian]

[11] Ivanov, O.V. (2011). Information infrastructure of the university as a means of providing a new quality of education. URL: https://cyberleninka.ru/article/n/informatsionnaya-infrastruktura-universiteta-kak-sredstvo-obespecheniya-novogo-kachestvaobrazovaniya (accessed 21.01.2019) [in Russian]

[12] Tiiu, Tenno. Pedagogical infrastuctures in e-learning enviroments as invisible bridges between navigation elements. URL https://www.ulapland.fil/oader.aspx?id=c8c856b7-cef0-4761-9d6e-f50fc0f45379 (accessed 21.01.2019)

[13] Carol, A. Twigg (1994). The Need For A National Learning Infrastructure. URL https://www.educause.edu/ir/library/html/nli0001.html (accessed 21.01.2019)

[14] Johnson, W. L. (2002). Natural Interaction with Pedagogical Agents in Virtual Environments. doi: https://doi.org/10.21236/ ada409186

[15] Jamshid, Beheshti, Eichenberg, C. (Ed.) (2012). Virtual Reality in Psychological, Medical and Pedagogical Applications. IntechOpen. doi: https://doi.org/10.5772/2607

[16] International Convention on the Preparation and Certification of Seafarers and Watchkeeping of 1978 (consolidated text with the Manila Amendment). Kyiv, Ukraina, 2012.(in Ukrainian)

[17] Koren, A.V. (2013). The use of Moodle's e-learning environment to create interactive training courses of the new generation / Internet-journal Naukovedenie, 1. URL: https://cyberleninka.ru/article/n/osobennosti-razrabotki-uchebnyh-kursov-sispolzovaniem-elektronnoy-obrazovatelnoy-sredy-moodle (accessed 21.01.2019) [in Russian]

[18] Sherman, M.I., Voloshynov, S.A., Popova, H.V (2018). Organization of blended learning in the electronic environment of LMS Moodle using the competency management functionality. URL: http://2018.moodlemoot.in.ua/course/view.php?id=39 (accessed 21.01.2019) (in Ukrainian)

[19] Kuharenko, V. M., Berezenska, S. M, Bugajchuk, K. L. (2016). Theory and practice of blended learning: monography. Miskdruk, Harkiv, Ukraine. 284 p. (in Ukrainian)

[20] Yurzhenko, A., Sherman, M., Popova, H. (2018). Interactive course «Maritime English» in the professional training of future» in Development trends in pedagogical and psychological sciences: the experience of countries of Eastern Europe and prospects of Ukraine, LV-1058. Baltija Publishing, Riga, Latvia. pp. 603-620.

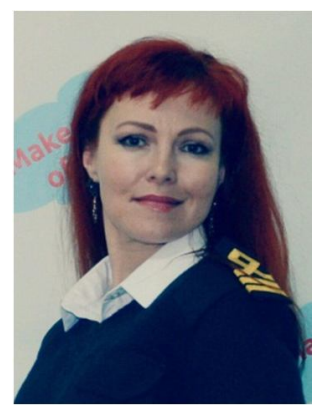

Попова Галина Вікторівна.

Завідувач лабораторії інноваційних технологій, Херсонська державна морська академія,

пр. Текстильників, 14а, кв.17, Херсон, Україна, 73028.

Tel. +38(066) 33-30-560. E-mail: spagalina@gmail.com

Popova Galina Viktorivna.

Chief of Innovative Technology Laboratory, Kherson State Maritime Academy,

pr. Tekstilnikiv, 14a., kv.17, Kherson, Ukraine, 73028.

Tel. +38(066) 33-30-560. E-mail: spagalina@gmail.com

ORCID: 0000-0002-6402-6475

\section{Citation (APA):}

Popova, G. (2019). "Virtual-real vessel" as an informational pedagogical infrastructure of the Kherson State Maritime Academy. Engineering and Educational Technologies, 7 (1), 79-88. doi: https://doi.org/10.30929/2307-9770.2019.07.01.08

\section{Цитування (ДСТУ 8302:2015):}

Попова Г. В. «Віртуально-реальне судно» як інфрормаційна педагогічна інфрраструктура Херсонської державної морської академії / Інженерні та освітні технології. 2019. Т. 7. № 1. С. 79-88. doi: https://doi.org/10.30929/2307-9770.2019.07.01.08

Обсяг cmammi: сторінок - 10 ; умовних друк. аркушів - 1,149 